\title{
Transition Studies The New Journals of the Network
}

\author{
Giorgio Dominese
}

Published online: 30 August 2012

(C) Springer-Verlag 2012

Transition Studies Network-CEEUN was founded in 2002 with the aim to connect a group of experts and university faculty in a program of cooperation devoted to research programs and specialized international postgraduate and doctoral courses. The Network grown fastly in the first 2 years and soon after the need of a scientific "voice" was fulfilled with the Review Mittelforum, published by Egea-Bocconi University Milan. Eight years ago a new step ahead: Transition Studies Review, published by Springer Wien-New York, became the official Journal. At the beginning, it was focusing on transition in Central and Southeast Europe, interpreting CEEUN mainly as a European University Network. Soon after the EU enlargement, the aims and scope were extended "beyond" the European Union 27 towards Russia, Ukraine, Caucasus, the Black Sea, Mediterranean, Near East, Central Asia. But the contemporary history, economic and geopolitical change and evolutions imposed a more courageous step forward. Beginning in 2005, a worldwide regional approach looking to Asia, Mediterranean, Eurasia and Latin America was implemented. The previous CEEUN was progressively substituted by Transition Studies Network-TSN. The new global "aims and scope" are now pursued with the Publisher Springer and three journals.

Transition Studies Network-involving now more than 400 internationally well known scientific members and 95 university departments, institutes and research centers-is engaged in many areas and programs. Transition Studies Review is its valuable scientific Journal. But a great upgrade has been taking place in these months. All the Bodies and Organs are interrelated with other two journals: on the one hand the Journal of Global Policy and Governance, based in Rome, Venice and

\footnotetext{
G. Dominese $(\bowtie)$

Tor Vergata University, Rome, Italy

e-mail: giorgio.dominese@uniroma2.it; gdominese@luiss.it

G. Dominese

Luiss University, Rome, Italy
} 
Udine universities, in partnership with the Institute of International Studies and the Center for Global Governance at the Fudan University in Shanghai, with a remarkable network of Chinese and Asian universities; the International Journal of Euro Mediterranean Studies based at the EMUNI University, Portorož, Slovenia on the other. Works are in progress to evaluate the feasibility of a fourth publication, the JFI-Journal of Finance and Insurance by 2013.

The JTSR scientific interests and fields are covering-with papers and articles submitted in particular by young, excellent faculty and experts-more intensively and widely the following fields of research: Europe and the World, EU enlargement future approach, the global governance economic, financial and policy framework and impact, where it focuses especially on growth theories, innovation and human capital, main advanced industrial sectors technologies, investments, international affairs, foreign policy choices and security, monetary policy and main currency areas, banking and insurance, development and area studies, social policies, environment and climate, culture and society, juridical and law studies, regional approach to global governance, peculiarities and critical challenges.

A special attention will be dedicated to the agro-industrial impact and interrelations with land management, innovative technologies, rural areas' economic growth, agronomic knowledge and techniques, European Union policies, standards and regulatory guidelines, international cooperation with the developing countries.

The future transition to open economy and institutional reforms, political and strategic challenges, governance implications, European, Mediterranean, AsiaPacific, Great Middle Eastern, Latin American and African perspectives are key topics and issues of this high-ranking journal. The Transatlantic and Asia-Pacific relations, security and international order represent, together with applied regional studies, a cornerstone of the Network's activity and of Transition Studies Review's contents as well as of the other two partner scientific publications: International Journal of Euro Mediterranean Studies and the new Journal of Global Policy and Governance. The Network is deeply committed to a wide range of transition issues related to quantitative modeling and tools to analyzing and researching economic, financial, strategic studies, social, cultural, environmental, juridical main issues.

Here you find the appointed Editorial leadership: Editor-in-Chief: Giorgio Dominese, President Transition Studies Network-CEEUN, Tor Vergata Rome University, LUISS University Rome; European Academy of Sciences and Arts, Salzburg; Co-Editors-in-Chief: Yugang Chen, Center Global Governance, Fudan University, Shanghai; Joseph Mifsud, President EMUNI-Euro Mediterranean University, Portorož, Slovenia; Managing Editor: Tran Dinh Lam, Director Center for Vietnamese and Southeast Asian Studies, Vietnam National University, Ho Chi Minh City. 